\title{
Белая горячка i White Fever. Jak za granicą (nie) czytają Jacka Hugo-Badera
}

\section{Белая горячка and White Fever: How Jacek Hugo-Bader Is (not) Read Abroad}

Abstract: The article is an attempt at analysing the foreign reception of Jacek Hugo-Badera's reportage books on the former USRR. Looking at the method of publishing and promoting the translations meant for the American market, the author points out the embedding of these texts in the global genology (the category of survival non-fiction). The testimonies of a professional and non-professional reception of White Fever in Ukraine (where the Polish school of reportage is an important point of reference) become in themselves a pretext to sketch out the post-colonial context. The author deems the lack of Russian translations of Hugo-Bader's books to be important. From a wider perspective, the proposed case study indicates the different ways of the Polish reportages being relevant abroad.

Keywords: reportage, Jacek Hugo-Bader, non-fiction, Polish school of reportage, reportage books on Russia, survival non-fiction, publishing market

Streszczenie: Artykuł jest próbą przeanalizowania zagranicznej recepcji książek reporterskich Jacka Hugo-Badera o byłym ZSRR. Przyglądając się sposobowi publikacji i promocji tłumaczeń przeznaczonych na rynek amerykański, autorka wskazuje na osadzanie tych tekstów w ramach globalnej genologii (kategorii survival non-fiction). Świadectwa profesjonalnego i nieprofesjonalnego odbioru Biatej gorączki na Ukrainie (gdzie „polska szkoła reportażu” jest ważnym punktem odniesienia) stają się z kolei pretekstem do zarysowania kontekstu postkolonialnego. Za znaczący autorka uznaje brak przekładów książek Hugo-Badera w Rosji. Proponowane case study w szerszej perspektywie wskazuje na różne możliwości zafunkcjonowania polskich reportaży za granicą.

Słowa kluczowe: reportaż, Jacek Hugo-Bader, non-fiction, „polska szkoła reportażu”, książki reporterskie o Rosji, survival non-fiction, rynek wydawniczy

„Polskie non-fiction, rozsławione przez Kapuścińskiego, to narodowa specjalność, jak ogórki kiszone i kiełbasa. Co jest wyjątkowego w tym literackim daniu?" - pytał Mikołaj Gliński w adresowanym do czytelnika i wydawcy globalnego 
przewodniku A Foreigner's Guide to Polish Reportage ${ }^{1}$, opublikowanym na łamach prowadzonego przez Instytut Adama Mickiewicza serwisu Culture.pl. Pisząc o Polsce jako „Eldorado reportażu”, Gliński próbuje odpowiedzieć na postawione przez siebie pytanie, wskazując na charakteryzujące (jego zdaniem) reportaż à la polonaise cechy: banalizm tematu uwznioślony formą, wysuwającą się na pierwszy plan literackość i prezentację poprzez szczegół. Trzymając się kulinarnej metaforyki, krytyczny odbiorca artykułu mającego promować polską literaturę za granicą powie, że to raczej Big Mac - codzienne życie jako pretekst do uogólnienia, eksperymenty stylistyczne i pogrywanie z fikcją oraz nasycenie tekstu szczegółem cechuje literackie niefikcje przynajmniej od momentu proklamowania przez Toma Wolfe'a Nowego Dziennikarstwa. Ujęciu narodowemu nie sprzyja dziś globalizacja literatury oraz jej wpływ na genologię - zarówno literacką, jak i dziennikarską. Amerykańskie non-fiction powoli zaczyna wypierać swojski reportaż również w Polsce, a polscy reportażyści sytuowani są przez wydawców w kontekstach zagranicznych bestsellerów.

Przykładem zewnętrznego spojrzenia na fenomen (fantazmat?) „polskiej szkoły reportażu" jest artykuł Brytyjki Susan Greenberg, akademiczki i dziennikarki związanej z „Guardianem”, opublikowany w książce zbiorowej Global Literary Journalism: Exploring the Journalistic Imagination. W tytule pojawia sie oczywiście nazwisko-marka: Kapuściński². Wychodząc od międzynarodowej sławy autora Imperium, autorka postanawia pochylić się nad fenomenem non-fiction znad Wisły jako „ważnego elementu kulturalnego dziedzictwa Polski”, ukształtowanego w PRL-u dzięki kreatywnej grze z cenzurą i podtrzymywanego obecnie - zdaniem autorki - wsparciem "Gazety Wyborczej” i jej reportażowego dodatku (rolę "GW” podkreśla Philip Gwyn Jones z londyńskiej oficyny Portobello Books, w której ukazały się książki między innymi Jacka Hugo-Badera i Wojciecha Tochmana). Chociaż Greenberg uznaje fenomen polskiej szkoły reportażu, w jej artykule pojawia się jednak konkurencyjny kontekst. Jean-Yves Potel powiedział badaczce: „Polscy pisarze i redaktorzy naśladowali amerykańską tradycję literacką. Suplement » Gazety Wyborczej《 został zainspirowany amerykańskimi magazynami, takimi jak New Yorker" ${ }^{3}$. Autorka zwraca również uwagę

1 M. Gliński, A Foreigner's Guide to Polish Reportage, https://culture.pl/en/article/a-foreigners-guide-to-polish-reportage, dostęp: 25.04.2021.

2 S. Greenberg, Kapuścinski and Beyond: The Polish School of Reportage [w:] Global Literary Journalism: Exploring the Journalistic Imagination, red. R.L. Keeble, J. Tulloch, New York 2012, s. 123-140.

3 Tamże, s. 135. Jeśli nie zaznaczono inaczej tłumaczenie fragmentu własne - I.A.B. Zupełnie inaczej patrzy na istotę polskiego reportażu brytyjski reporter Ben Judah, autor Nowych londyńczyków, w których moim zdaniem można dopatrywać się inspiracji reporterskim modus operandi Jacka Hugo-Badera. W jednym z wywiadów Judah mówił: „Brytyjska literatura faktu jest dziś naznaczona przez »New Yorkera «, ale nie czuję tego, co Christopher Hitchens określit jako » przyciąganie grawitacyjne wielkiej amerykańskiej planety«. Żałuję, że nie potrafię pisać jak mistrzowie reportażu z Włoch, Francji i Polski. Jako nastolatek zafascynowałem się Kaputt Curzia Malaparte, wielokrotnie przeczytałem książki Jacka Hugo-Badera i Ryszarda Kapuścińskiego. Żaden 
na podążanie za globalnymi trendami dotyczącymi eksperymentowania z formą. Wątek amerykańskich inspiracji powraca w artykułach ukraińskich badaczek, Lilii Shutyak i Khristiny Golovko, które „polską szkołę reportażu” uważają wręcz za unikatowy - ale jednak - wariant amerykańskiego Nowego Dziennikarstwa ${ }^{4}$.

W zagranicznych artykułach dotyczących polskiej literatury faktu często przywoływane jest nazwisko Jacka Hugo-Badera, któremu zostanie poświęcony niniejszy szkic. Reportera piszącego o byłym ZSRR, a więc podejmującego temat globalnie atrakcyjny i wpisującego się tym samym w tradycję zapoczątkowaną przez Kapuścińskiego jego osadzonym już w międzynarodowym kanonie Imperium. Pisarza osobnego, promowanego jako wyrazisty głos polskiego reportażu, którego jednak łatwo jest wpisać w globalne trendy wydawnicze. W artykule chciałabym się skupić na recepcji brytyjskiej i amerykańskiej oraz rosyjskiej i ukraińskiej. Dokonując takiego wyborus ${ }^{5}$, koncentruję się na dwóch tematach dotyczących możliwości (lub nie) zafunkcjonowania polskiego reportażu w zagranicznym obiegu wydawniczym. Tłumaczenia anglojęzyczne omówię w kontekście globalizacji non-fiction (zarówno tematycznej, jak i formalnej). Źródła rosyjskie i ukraińskie interesują mnie w odniesieniu do reporterskiego punktu widzenia, który za Małgorzatą Czermińską ${ }^{6}$ w przypadku Hugo-Badera doprecyzuję jako: swój o innych dla swoich. W przypadku czytelnika rosyjskiego zmiana odbiorcy modelowego na konkretnego oznacza przesunięcie i stworzenie innej trajektorii komunikacyjnej: swój o innych dla innych (a może inny o swoich dla swoich?). Zastanowię się nad tym, co może z tej zmiany wynikać.

\section{Korespondent z Polszy ${ }^{7}$}

Jacek Hugo-Bader od 1991 roku jest dziennikarzem „Gazety Wyborczej”. Pod czujnym okiem Małgorzaty Szejnert, drugiej po Hannie Krall szefowej „Magazynu” (dziś - „Dużego Formatu”), zaczynał od opisywania transformacyjnej

brytyjski i amerykański reportaż nie może się równać z polskim" (https://thebailliegiffordprize. co.uk/news/ben-judah-interview, dostęp: 23.05.2021).

4 H.I. Golovko, Польська школа художнього репортажу: історія та процес розвиткух, „Соціальні комунікаціi”, http://pvs.uad.lviv.ua/static/media/1-77/12.pdf, dostęp: 28.05.2021; taż,

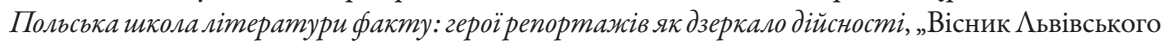

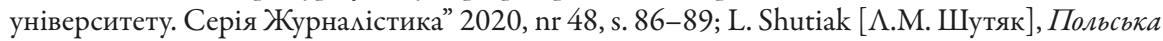
школа художнього репортаж, „Інформаційне суспільство” 2016, nr 23, s. 31-36.

5 Przeczytałam wszystkie teksty krytyczne dostępne w internecie, a do analizy wybrałam te, których autorzy skupiali się na perspektywie polskiego reportera, wychodząc poza powierzchowne uwagi na temat treści. Świadectwa odbioru profesjonalnego (artykuły naukowe, krytyka prasowa) zestawiłam z recenzjami „obywatelskimi” (Goodreads).

6 M. Czermińska, „Punkt widzenia” jako kategoria antropologiczna i narracyjna w prozie niefikcjonalnej, „Teksty Drugie” 2003, nr 2-3, s. 11-27.

7 To tytuł planowanego cyklu dokumentalnego o Hugo-Baderze, zaproponowanego przez Pawła Łozińskiego stacji TVN. Powstały tylko dwa pilotażowe odcinki. 
Polski, zwłaszcza prowincjonalnej. Dość niespodziewanie dla samego siebie po zleconym wywiadzie z Michaiłem Kałasznikowem stał się ekspertem od byłego ZSRR. Od ponad 10 lat przechodzi od formy gazetowej do książkowej, od roli doraźnego dziennikarza informacyjnego do pisarza. Publikowane reportaże długometrażowe są świadectwem dwóch dominujących kręgów zainteresowań reporterskich. Książki krajowe to Audyt i Skucha, w planach jest domykająca część trylogii - Refluks ${ }^{8}$. W rajskiej dolinie wśród zielska, Biata goraczka, Dzienniki kotymskie i Szamańska choroba to opowieści o dawnym ZSRR. O ile tematyka polska nie spotkała się z globalnym zainteresowaniem, o tyle książki o Rosji już tak. Biata gorączka przełożona została na język angielski ${ }^{9}$, ukraiński ${ }^{10}$, węgierski ${ }^{11}$, francuski ${ }^{12}$, hebrajski ${ }^{13}$, niemiecki ${ }^{14}$, włoski ${ }^{15}$, szwedzki ${ }^{16}$, hiszpań$\mathrm{ski}^{17}$, bułgarski ${ }^{18}$. Dzienniki kotymskie - na węgierski ${ }^{19}$, angielski ${ }^{20}$, francuski ${ }^{21}$, słowacki ${ }^{22}$ oraz włoski ${ }^{23}$.

Biata goraczka jest pierwszym długometrażowym reportażem Hugo-Badera. Punktem wyjścia do ekskursji z Moskwy do Władywostoku, a zarazem wstępną, pretekstową trasą wyprawy, była lektura Reportażu z XXI wieku. W propagandowej książce z 1957 roku dziennikarze „Komsomolskiej Prawdy”, Michaił Wasiljew i Siergiej Guszczew, snuli futurystyczne rojenia o znakomitej przyszłości radzieckiej nauki. Niektóre z nich nawet się sprawdziły (futurolodzy przewidzieli na przykład internet i telefonię komórkową), choć nie dzięki Rosjanom. Już na etapie planowania wyprawy wiadomo było, że takie zestawienie radzieckiego steampunku z rzeczywistością zastaną wywoła efekt komiczny. Jak w tej moskiewskiej refleksji:

8 Wyjątkiem jest Dtugi film o mitości, który dotyczy polskiego środowiska górskiego.

9 J. Hugo-Bader, White Fever: A Journey to the Frozen Siberia, thum. A. Lloyd-Jones, Berkeley 2012; London 2012.

10 Tenże, Бiлa zapraqka, tłum. O. Sluvynsky, Kijów 2012.

11 Tenże, Fehér láz, tłum. L. Pálfalvi, Z. Mihályi, Budapest 2012.

12 Tenże, La Fièvre blanche: De Moscou à Vladivostok, tłum. A. Żuk, Lausanne 2012.

13 Tenże, ריביס לש אופקה הבלל עסמ - הנבל תחדק, [Qadahat lbanab], ttum. M. Stankiewicz, Z. Kinneret, Or Yehuda 2013.

14 Tenże, Ins eisige Herz Sibiriens, tłum. B. Voelkel, München 2014.

15 Tenże, Febbre bianca, tłum. M. Borejczuk, Rovereto 2014.

16 Tenże, Vit feber, thum. L. Mendoza Asberg, Stokholm 2014.

17 Tenże, El delirio blanco, tłum. E. Rubio, M. Słyk, Madryt 2016, wyd. meksykańskie: La fiebre blanca, tłum. A. Styczyńska, Oaxaca de Juárez 2015.

18 Tenże, Алкохолен делир-литературни репортажи за Русия от XXI век, thum. D. Dencheva, Sofia 2019.

19 Tenże, Kolimai napló, tłum. Z. Mihályi, Budapest 2013.

20 Tenże, Kolyma Diaries: A Journey into Russia's Haunted Hinterland, tłum. A. Lloyd-Jones, London 2014.

21 Tenże, Journal de la Kolyma, tłum. A. Żuk, Lausanne 2015.

22 Tenże, Kolymské denniky, tłum. P. Oriešek, Krásno nad Kysucou 2017.

23 Tenże, I diari della Kolyma. Viaggio ai confini spettrali della Russia, thum. M. Vanchetti, Rovereto 2018. 
Wódka od mrozu była tak gęsta, że ledwo ciekła z butelki. A przecież nad Moskwą miało już grzać i świecić sztuczne słońce o mocy miliona kilowatów. I miało być tylko pięć milionów mieszkańców. I nikt głodny, nikt nie choruje na gruźlicę ani na raka, nikt nie jest nawet zmęczony, a więc prawie nie trzeba spać. Miało nie być samochodów, śniegu na ulicach i cuchnących zsypów w mieszkaniach.

$\mathrm{Z}$ tej listy udało się zrealizować tylko ostatnie marzenie. I to częściowo, bo teraz cuchnie na klatkach schodowych ${ }^{24}$.

Do przygody z książką, którą podrzucił mu Mariusz Szczygieł, Hugo-Bader wymyślił zgrabną historię: postanawia zrobić sobie prezent na pięćdziesiąte urodziny, a urodził się właśnie w tym roku, w którym Wasiljew i Głuszczew dostali polecenie opisania, „jak się będzie żyło w Związku Radzieckim za jakieś pięćdziesiąt lat, powiedzmy w dziewięćdziesiątą rocznicę Wielkiej Socjalistycznej Rewolucji Październikowej" ${ }^{25}$. Absurdalne fragmenty Reportażu XXI wieku - o aucie w kształcie kropli, kolonizacji Księżyca, wyhodowaniu głowy kapusty o średnicy przekraczającej metr - ubarwiają relację Hugo-Badera. Hybrydyczną, gdyż w jej skład wchodzi i słowniczek, i wywiady z ekspertami, i fragmenty dziennika podróży, a także reportaże, które mogłoby funkcjonować samodzielnie, bo każdy ma inny temat, na przykład o rosyjskiej religijności, szamanach, górnikach i Krymie. Uszczegółowiona trasa, którą reporter przebywa uazem, przedstawiona zostaje w rozdziale wstępnym, w którym skupia się on na filozofii swojej podróży. Prowadzi ona z Moskwy do Kazania poprzez Ufę, Ural, Czelabińsk, Omsk, Nowosybirsk aż do Krasnojarska. Stamtąd pisarz udaje się do Chakasji i Tuwy. Ponownie przez Krasnojarsk przeprawia się do Irkucka - skąd wraca do Polski na święta, bo poprosiła go o to żona. Wyprawę kontynuuje wokół Bajkału, dociera do Ułan Ude i kieruje się w stronę Czyty, „za którą kończy się normalna droga, asfalt, ludzkie siedziby i cywilizacja" ${ }^{26}$, a zaczynają góry, bagna, śnieg i tajga. Podąża do Chabarowska i Władywostoku, gdzie wysłużony uaz kończy bieg.

Podróżując uazem, zabiera z drogi autostopowiczów za zgodę na zdjęcie i możliwość wysłuchania historii współpasażera, raz - zniżkę na „usługę seksualną” (nie skorzysta). Raczy się kiełbasą myśliwską „twardą jak patyk”, śpi w samochodzie albo prosi o nocleg miejscowych. Mierzy się z zimnem - na Syberii nosi gogle narciarskie uszczelnione chustką do nosa. W trasie prowadzi dziennik, w którym odnotowuje między innymi perypetie związane z naprawami auta i konfrontacją z rosyjską biurokracją, a także trudy podróży wynikające z nieprzyjaznej dla przyjezdnych syberyjskiej aury. Wizytując Ufę, reporter szuka nosicieli wirusa HIV. W Kazaniu przeprowadza wywiad z Miss Positive (córka kołchoźników przez chorobę trafiła do show-biznesu). W sercu tajgi zwiedza „ziemię obiecaną”

24 Tenże, Biata goraczka, Wołowiec 2011, s. 57.

25 Tamże, s. 13.

26 Tamże, s. 20. 
Kościoła Ostatniego Testamentu, próbując odpowiedzieć na pytanie o przyczyny rosyjskiej religijności poza Kościołem prawosławnym (dodatkiem do reportażu jest wywiad z „ekspertem” - prawosławnym filozofem i komentatorem religijnym). W republice Tuwy, w syberyjskiej części Rosji, Hugo-Bader gości u szamanów. W szpitalu dziecięcym uczestniczy w „zapuszczaniu ducha” w chłopca umierającego na raka żołądka, składa wizytę prezydentowi Tuwińskiej Wspólnoty Szamanów Dungur i szefowej Religijnej Wspólnoty Tos-Deer (Dziewięć Niebios) oraz daje odprawić nad sobą rytuał („dokąd ja odleciałem? Usnąłem na siedząco? Umarłem na trochę ?"27). Tytuł książki - Biata gorączka - pochodzi z centralnego reportażu o Ewenkach, jednym z rdzennych narodów zamieszkujących Syberię, wybijanych przez obłęd opilczy, czyli alkoholową psychozę, którą przepytywana przez reportera lekarka-narkolog opisuje następująco:

Pojawia się dwa, trzy dni po przerwaniu pijackiego ciągu. Zaczyna się od bezsenności, niepokoju, a potem przychodzą halucynacje. U jednych wzrokowe, u innych słuchowe. Widzą dziwne, bardzo ruchliwe postaci, stwory, zwierzęta. Styszą głosy, które ich obrażają, grożą im, wymyślają, oskarżają, albo każą sobie coś zrobić, na przykład popełnić samobójstwo albo wziąć siekierę i odrąbać sobie rękę ${ }^{28}$.

Nawet, jeśli ten wybór podyktowany został tylko chwytliwością hasła, ustawia interpretację książki. Po pierwsze - stawia w centrum mniejszość. Wybór Ewenków to tylko egzemplifikacja, bo opisywane przez Hugo-Badera zjawisko dotyczy też Buriatów, Mongołów, Tuwińców, Czukczów i innych ludów Azji Północnej, które mają słabą tolerancję na alkohol i których Rosjanie najpierw sowietyzowali, a teraz dowcipkują z nich, jak Polacy z mieszkańców Wąchocka, a Amerykanie z Polaczków (to już porównanie autora). Małe, rdzenne narody Rosji powoli giną. Po drugie - bardzo jaskrawo rozpad Imperium zaprezentowany tu został na konkretnym przykładzie. Wygasanie sowchozu (kiedy upadł, państwo wydzierżawiło teren rosyjskiemu oligarsze) przedstawiane jest poprzez zgrabny zabieg enumeracji - niby beznamiętne liczenie ofiar alkoholu (reporter zagląda do miejscowej księgi zgonów). Biała gorączka pociągnęła w niebyt 21 pasterzy: umarł z przepicia, spłonął żywcem, strzelił sobie w głowę, powiesił się. Po trzecie - Biata goraczka opowiada o traumie, i to traumie dziedziczonej.

Opowieść o podróży z Moskwy do Władywostoku to pierwsza część Biatej gorączki. W drugiej Hugo-Bader zdecydował się umieścić dziewięć reportaży napisanych wcześniej lub później i publikowanych w „Wyborczej”: pokazującą relacje między Rosją a Ukrainą pocztówkę z Jałty („Las Vegas dla ubogich”), reportaż o dyrkach w Doniecku (nielegalnych kopalniach węgla, które reporter wizytował z ekipą filmową Pawła Łozińskiego), refleksje z Mołdawii - najbiedniejszego kraju Europy, w którym kwitnie handel organami i seksniewolnictwo,

27 Tamże, s. 144.

28 Tamże, s. 187. 
zapiski z Naddniestrza (nieuznawanego państwa, traktowanego jako autonomiczny region Mołdawii, w którym „zakonserwowano kawałeczek Związku Radzieckiego" ${ }^{29}$ ), sprawozdanie z wizyty w Tiumieniu, stolicy nafty - „rosyjskim Teksasie" (tu pisarz poluje na ludzi sukcesu), tekst o podróży nad Bajkał, w którą zabrał piętnastoletniego syna, a także zapis włóczęgi po Moskwie z bezdomną. Hugo-Bader spotyka się też z archeologiem Lwem Klejnem, który napisał książkę o więziennym życiu homoseksualistów, oraz z Wiktorem Łazarewiczem Ginzburgiem, członkiem Rosyjskiej Akademii Nauk, fizykiem noblistą - jedynym żyjącym bohaterem Reportażu z XXI wieku.

Drugi pełnometrażowy reportaż Hugo-Badera, Dzienniki kotymskie, również ujęty jest w ramę trasy. To zapis podróży Traktem Kołymskim, z Magadanu do Jakucka. Przez „zdziczały kraj” reporter pędzi autostopem - niekiedy w towarzystwie błatnych (przestępców) - a śpi tam, gdzie uda mu się „wydziadować” nocleg. Za interteksty służą mu tym razem kanoniczne dzieła literatury gułagowej - Archipelag GUモag Aleksandra Sołżenicyna i Opowiadania kotymskie Warłama Szalamowa, ale znów (jak w przypadku Reportażu z XXI wieku) traktowane tylko pretekstowo. Choć reporter odwiedza zeków i zeczki (rozmawia między innymi z kobietą, która pamięta Szałamowa), już na wstępie zaznacza, że „u mnie nie będzie o Gułagu, obozach, więźniach, głodzie, śmierci i torturach"30". Interesuje go przede wszystkim życie codzienne:

Jadę na Kołymę, żeby zobaczyć, jak żyje się w takim miejscu, na takim cmentarzu. Najdłuższym. Można się tu kochać, śmiać, krzyczeć z radości? A jak tu się płacze, płodzi i wychowuje dzieci, zarabia, pije wódkę, umiera? O tym chcę pisać. I o tym, co tu jedzą, jak płuczą złoto, pieką chleb, modlą się, leczą, marzą, walczą, biją po mordach...

Gdy ląduję, w aeroporcie pod Magadanem czytam wielki napis: WITAJCIE NA KOŁYMIE - W ZŁOTYM SERCU ROSJI ${ }^{31}$.

W tym marketingowym haśle zawarty jest cały paradoks Kołymy, która stoi surowcami strategicznymi - złotem, srebrem, platyną, uranem, kobaltem, rtęcią, cyną, ołowiem... - wylicza reporter. Te surowce latami wydobywali więźniowie, teraz pasą się nimi oligarchowie. Tacy jak kołymski „król złota” Aleksander Basanski, który podstępem wcisnął Hugo-Baderowi samorodek i plik banknotów (reporter postanowił przekazać go na cele charytatywne).

Książka jest połączeniem dziennika podróży, reportaży opartych na wywiadach i migawek z trasy. Z podróżnych drobiazgów - na przykład koniec sezonu połowu łososi reporter świętuje w baraku inspektora straży rybackiej z czekistą

29 Tamże, s. 291.

30 J. Hugo-Bader, Dzienniki kotymskie, Wołowiec 2011, s. 18.

31 Tamże, s. 22. 
i błatnym, którzy grają w karty („W baraku nad Morzem Ochockim odradza się stary, stalinowski sojusz błatnych, czyli kasty zawodowych przestępców, z bezpieką, z całym aparatem przemocy"32), odwiedza osadę poszukiwaczy złota, biesiaduje na złomowisku i daje z siebie zdjąć urok w jakuckiej Komunie Roboczej wyłania się panorama „złotego serca Rosji”. Zarówno w Dzienniku kotymskim, jak i Biatej goraczce wyraźnie widać sposób reporterskiego działania Hugo-Badera kolekcjonera osobliwości, „ludzkich brylantów”, freaków, którym dziennikarz odbiera i przerabia literacko historie życia. W Biatej goraczce takim „brylantem” jest napotkany w trasie Chińczyk Czin Li, bibliotekarz, który po stracie pracy kupił konia i jedzie do ojczyzny. Podróżuje bez pieniędzy i śpi w plenerze. „Polowy mundur, pod spodem marynarka, a do tego buciory, które ledwo mieszczą się w strzemionach. (...) Twarz prawie czarna, brudna i ogorzała od słońca, sucha i wynędzniała. (...) Wyglądał jak mongolski wojownik, tylko mundur i kierunek nie ten. Jechał na wschód"33. W Dziennikach kotymskich - Jurij Sałatin, król wysypiska śmieci i szalony konstruktor:

A jaki piękny! W starej lotniczej kurtce na kożuchu, kapitańskiej czapce i błękitnym golfie na gołe ciało z wielkimi dziurami pod pachami. Sprężysty, podciągnięty, wyprostowany. I postawny. Lat sześćdziesiąt siedem, gęba prawe czarna, ogorzała i ten bezczelny, arogancki, łobuzerski błysk w jasnych, czystych oczach pod kolor swetra. Prawdziwy krasawiec. Ręce wielkie, silne, szorstkie. Na milę widać, że oficer. Powiedziałbyś: kapitan potrzaskanego okrętu, który wraca spod Trafalgaru, a nie złomiarz z Jagodnego. Dowódca żaglowca, a nie miejscowego wysypiska ${ }^{34}$.

Doskonałym podsumowaniem kolekcjonerstwa Hugo-Badera jest cytat z Biatej goraczki, w której reporter przedstawia się czytelnikowi jako tropiciel śladów - niczym bohaterowie Jamesa Fenimore’a Coopera czy jego rosyjskiego odpowiednika, Władimira Arsenjewa. Tropy rozczytuje z zachowanych w śniegu śladów moczu ${ }^{35}$.

\section{White Fever. Survival non-fiction}

Tłumaczką Jacka Hugo-Badera na angielski jest Antonia Lloyd-Jones, która w jednym z wywiadów opowiadała o promowaniu polskiej literatury i przekonywaniu wydawców do jej publikacji jako o „syzyfowej pracy”36.

32 Tamże, s. 33.

33 J. Hugo-Bader, Biata goraczka, dz. cyt., s. 26.

34 Tenże, Dzienniki, dz. cyt., s. 168.

35 Tenże, Biata goraczka, dz. cyt., s. 21-22.

36 Antonia Lloyd-Jones and Her Authors, http://authors-translators.blogspot.com/2016/01/ antonia-lloyd-jones-and-her-authors.html, dostęp: 27.05.2021. 
Konkurencja jest ogromna, co roku ukazuje się mnóstwo książek po angielsku, wszystkie przetłumaczone publikacje borykają się z tym samym problemem. Pomimo największych wysiłków wydawców, marketing to ciężka praca, bo większość brytyjskiego i amerykańskiego społeczeństwa jest zamknięta na obcą literaturę i na ogół woli przewidywalne lektury niż to, co nieznane. (...) Jako tłumacz z mniej znanej literatury, myślę, że częścią mojej roli jest pełnienie funkcji „ambasadora” dla niej i robię wszystko, co w mojej mocy, aby promować własne tłumaczenia i ogólnie literaturę polską

- mówiła.

Nic dziwnego, że książki Jacka Hugo-Badera wpisane zostały w model funkcjonowania globalnego rynku wydawniczego. Sygnalizują to już rozwinięcia tytułów. Biata goraczka to White Fever: A Journey to the Frozen Heart of Siberia. Dzienniki kotymskie zyskały natomiast podtytul A Journey into Russia's Haunted Hinterland. Tę decyzję interpretuję jako gest lokujący książkę Hugo-Badera w sieci publikacji wspierających, w tym wypadku trawelogów, czyli relacji z podróży, z doprecyzowaniem - chodzi o ekskursje o charakterze przygodowo-surwiwalowym. Globalna genologia o amerykańskim rodowodzie wyróżnia kategorię wspomnieniowo-sprawozdawczych tekstów opatrzonych etykietą non-fiction survival. Wybierający White Fever z półki księgarni przyszły czytelnik mógłby założyć, że w toku lektury będzie obcował z opowieścią o przetrwaniu podróżnika wydanego na pastwę surowej natury - jak czytając Biatą ciemność Davida Granna czy Wszystko za życie Jona Krakauera. Natomiast hasło (czy też, jak byśmy dzisiaj powiedzieli, słowo kluczowe) „podróż na Syberię” automatycznie nasuwa czytelnikowi anglojęzycznemu skojarzenie z rosyjską trylogią Colina Thubrona, zwłaszcza In Siberia (1999) oraz Travels in Siberia Iana Fraziera (2010), a więc klasycznymi pograniczami literatury podróżniczej i memuaru w wariancie brytyjskim (Thubron) i amerykańskim (Frazier). Porównanie ich z Biatą goraczką i Dziennikami kotymskimi pozwoli na wskazanie różnic, a więc i potencjalnych zawiedzionych oczekiwań globalnego odbiorcy.

Thubron to marka. Rocznik 1939, należy do złotego pokolenia brytyjskich podróżników dżentelmenów (takich jak Bruce Chatwin, Eric Newby, Jonathan Raban i Paul Theroux), wychowanych w szkołach z internatem, które zapewniły im - jak wspomniał w jednym z wywiadów - twardą skórę ${ }^{37}$. Współpracował między innymi z „The New York Timesem”, dostał Medal Lawrence'a z Arabii, Nagrodą Szkockiego Towarzystwa Podróżniczego oraz tytuł komandora Orderu Imperium Brytyjskiego. Po Syberii to domknięcie trylogii, na którą składają się też Among the Russians (1983) oraz Utracone serce Azji (1994). Zbierając materiały do tej książki, Thubron przebywa mniej więcej taką trasę jak Hugo-Bader przeprowadzający research do Biatej goraczki i Dzienników kotymskich.

37 V. Roy, The Constant Traveller, „The Hindu”, 4.01.2014, https://www.thehindu.com/ features/magazine/the-constant-traveller/article5538257.ece, dostęp: 2.05.2021. 
W przeciwieństwie do autora $W$ rajskiej dolinie wśród zielska, którego interesują przede wszystkim spotykani w podróży ludzie i ich opowieści, Thubron nacisk kładzie na kulturę i historię. $Z$ upodobaniem zwiedza muzea, cerkwie prawosławne, klasztory buddyjskie i kościoły. Religijność Rosjan i rdzennych narodów Syberii bardzo go zajmuje.

Próbuję dotrzeć do sedna Syberii, choć pewnie go nie ma; chciałbym choć przez chwilę być świadkiem, jak Syberia dźwiga się z ruin po komunizmie - podpatrzyć, jak odwieczna, nieodparta potrzeba wiary wpada w plątaninę kanałów i płynie dalej pod inną nazwą. Bo nie umiałem sobie wyobrazić Rosji bez wiary ${ }^{38}$

- pisze. Pod tym kątem przyglądał się rozkładającemu się Imperium już w Utraconym sercu Azji. Sprawdzając, jak byłe republiki krzepną po uniezależnieniu się od Rosji, w momencie gdy „radziecka fala przyboju odstąpiła nagle od tych tajemniczych państw muzułmańskich i zostawiła je nagie w obliczu niezawisłości" ${ }^{39}$, meandrując po postkolonialnym krajobrazie Kazachstanu, Kirgistanu, Tadżykistanu, Turkmenistanu i Uzbekistanu, Thubron koncentrował się na rozważaniach na temat tożsamości zbiorowej i historii - odtwarzanej i zamazywanej. $\mathrm{Z}$ jednej strony było to poszukiwanie wyrywanych w procesie sowietyzacji korzeni, które doprowadziło do utraty łączności z dziedzictwem, z drugiej - zamazywanie śladów wchłonięcia przez Imperium, „amputującego" historię kolonizowanych. Odnotowując padające pomniki Włodzimierza Lenina i zmienianie nazw placów Karola Marksa, w Utraconym sercu Azji Thubron podkreślał, jak marzenie o świecie bez granic przekształca się w konkurencyjną wobec sowietyzacji opcję jedności w religii (muzułmańskiej). Takie syntetyzujące ujęcie (bliższe perspektywie Kapuścińskiego niż optyce „wałęsającego się psa”, którą praktykuje Hugo-Bader) dominuje również w Po Syberii - w tej książce Thubron prognozuje mającą nastąpić europeizację Rosji, w Syberii widząc ostoję „rosyjskości”. Metaforą walki pomiędzy Europą a Azją staje się dla Thubrona Lodowa Księżniczka z Ałtaju, o którą toczy się rywalizacja - czy jest kaukazoidalna czy mongoidalna? Gdzie powinna się znaleźć w Muzeum Kultury Syberyjskiej w Akademgorodoku (Nowosybirsk) czy w Gornoałtajsku - stolicy Republiki Ałtaju, tam, gdzie wydobyto ją z kurhanu i gdzie rozwijała się dawna kultura nomadów? Świadomość pisania dla czytelnika globalnego odsłaniają używane przez Thubrona porównania. W Po Syberii nazywa Kozaków kowbojami Dzikiego Wschodu, staroobrzędowców przyrównuje do mormonów, a mieszkańców Syberii - do amerykańskich pionierów.

Podejście do tematu Thubrona i Hugo-Badera różni też poziom zaangażowania cielesnego. O ile Brytyjczyk podchodzi do Rosjan i rdzennych narodów Syberii z rezerwą, o tyle Hugo-Bader praktykuje ulubioną przez siebie strategię

38 C. Thubron, Po Syberii, thum. D. Kozińska, Wołowiec 2011, s. 119.

39 Tenże, Utracone serce Azji, tłum. D. Kozińska, Wołowiec 2012, s. 14. 
wchodzenia w cudzą skórę. Najlepiej tę różnicę pokazuje wątek szamański i tematyka sensatów, obecne zarówno w Biatejgoraczce, jak i w Po Syberii Thubrona. W Brytyjczyku obecność szamańskich stowarzyszeń wzbudza sceptycyzm. W Instytucie Medycyny Klinicznej i Eksperymentalnej co prawda dał się zamknąć w komorze hipomagnetycznej, ale doświadczenie racjonalizuje: „Nie jestem kosmofobem. Jestem po prostu Anglikiem" ${ }^{30}$. Hugo-Bader uruchamia w tym kontekście pakt dyskursywnej labilności, uchylając się od akcentowania zachodniego, zracjonalizowanego oglądu. Wybraną przez autora Biatej gorączki strategię można nazwać lawirowaniem pomiędzy perspektywą konwertyty a Marsjanina (odnoszę się tu do znanej koncepcji Freda Davisa ${ }^{41}$.

Stuprocentowym Marsjaninem jest natomiast w Rosji Ian Frazier. Jego monumentalne Podróże po Syberii są zapisem pięciu wypraw, a zarazem dokumentacją powolnego przybliżania się Amerykanina do tematyki rosyjskiej, która początkowo wydaje mu się niebywale egzotyczna. Dziennikarz z upodobaniem relacjonuje szok kulturowy, który stał się jego udziałem wraz z postawieniem stopy na lotnisku Szeremetiewo. W toalecie ktoś zmywa naczynia, przychodząc w gości, trzeba zdjąć buty i włożyć kapcie bez pięt, na lotnisku w Omsku stan sanitariatów prowokuje Fraziera do wygłoszenia korygującego wezwania do „partnerów handlowych" Amerykanów. W podróży do Ułan Ude uwaga Fraziera koncentruje się na - jakżeby inaczej - hałaśliwych przedstawicielach rosyjskiej mafii. Frazier jest w Rosji obcym w dziwnym kraju, a rusofilia, do której namiętnie się przyznaje, motywowana jest pokoleniowymi doświadczeniami - dziennikarz wielokrotnie odwołuje się do zimnej wojny i rywalizacji dwóch mocarstw, wskazując zarazem na symboliczne podobieństwo Syberii i Ameryki: „Poza swoim rzeczywistym, materialnym jestestwem, obie są sztucznymi wytworami, konstruktami mentalnymi” ${ }^{2}$, bo „Syberia” to w Ameryce synonim czegoś gorszego, „Ameryka" w Rosji natomiast jest oznaką luksusu. Symptomatyczne, że od takiej właśnie refleksji Frazier rozpoczyna swoją książkę, niewolną od wyższościowych przesądów, choć Frazier stara się jednak swój ogląd Rosji usamodzielnić. W podróży pierwszej towarzyszy mu Katia, przewodniczka i tłumaczka, od lat mieszkająca w Ameryce i nastawiona równie sceptycznie do lokalnych „dziwactw” co Frazier. W tym czasie dziennikarz zaczyna jednak uczyć się rosyjskiego i w podróż z Alaski na Czukotkę leci już bez tłumacza, choć w kilkuosobowej grupie. Trzecią ekskursję syberyjską, autem, finansuje mu „New Yorker”, ale obecność lokalnego przewodnika i kierowcy wpływa na trasę - Frazier odnotowuje, że Rosjanie nie chcą pokazywać mu obozów zesłańców, co generuje konflikty. Czwarta wyprawa Fraziera to podróż na Syberię zimą, a po raz ostatni wyrusza sam, już bez pośredników. Recenzując książkę Fraziera o Syberii, dziennikarz „New York

40 Tenże, Po Syberii, dz. cyt., s. 101.

41 F. Davis, The Martian and the Convert, „Ontological Polarities in Social Research, Urban Life and Culture", vol. 2, iss. 3, 1973, s. 333-343.

42 I. Frazier, Podróże po Syberii, thum. J. Korpanty, Warszawa 2013, s. 12. 
Timesa" nazwał tę publikację podróżniczą połączeniem Archipelagu GUŁag Aleksandra Sołżenicyna z $W$ drodze Jacka Kerouaca ${ }^{43}$, co jest raczej przykładem stosowania recenzenckich komunałów podyktowanego najoczywistszymi skojarzeniami niż konsekwencją wnikliwej lektury.

W Podróżach po Syberii Frazier wspomina o trzech „syberyjskich gatunkach literackich”: podróżniczym, łagrowym oraz powieści łotrzykowskiej. O ile książki Thubrona i Fraziera są konwencjonalnymi narracjami podróżniczymi, o solidnej podbudowie historycznej i geograficznej (a więc pełniącymi też funkcję poznawczą), o tyle publikacje Hugo-Badera nie dają się tak łatwo wpisać w gatunkowe konwencje. Problemem dla wydawców okazała się na przykład forma Biatej goraczki. Przypomnijmy, że wersja oryginalna opublikowana przez Czarne dzieli się na zapis podróży z Moskwy do Władywostoku z Reportażem z XXI wieku Guszczewa i Wasiljewa pod pachą oraz reportaże krótkometrażowe z byłego ZSRR. Jest to więc połączenie trawelogu pomyślanego jako całość ze zbiorem publikowanych już w prasie tekstów składających się na drugą część książki. Angielski wydawca postawił warunek: autor ma się ograniczyć do reportaży spiętych motywem drogi. Jacek Hugo-Bader na to przystał, ale ponieważ było mu żal tekstów, które nie weszłyby do książki, zmodyfikował nieco post factum trasę podróży. Dodał też do White Fever swój reportaż o Kałasznikowie ze zbioru $W$ rajskiej dolinie wśród zielska.

Intuicje wydawcy potwierdza recepcja czytelników nieprofesjonalnych. Z lektury minirecenzji publikowanych w aplikacji Goodreads można wywnioskować, że Amerykanów gatunkowa niejednoznaczność (ni to trawelog, ni opowieść o współczesnej Rosji) odstręcza. Odbiorcy utyskują, że nie tego się spodziewali, wybierając lekturę z działu podróżniczego i czytając na okładce zachęcające streszczenie skupiające się na podróży łazikiem z Moskwy do Władywostoku. Zwracają też uwagę na niedostosowanie tekstu do anglojęzycznego odbiorcy, który nie wie o Rosji tyle, co polskojęzyczny czytelnik ${ }^{44}$ - mnogość kontekstów historycznych obecna w książkach Thubrona i Fraziera najwyraźniej lepiej zaspokaja poznawcze apetyty. Najcięższe działa wytacza Australijczyk Andrew Davis: „To jedna z najgorszych książek jakie w życiu czytałem. Oczekiwałem opisu podróży przez Syberię, a dostałem migawki o hippisach, pijakach, narkomanach i muzycznych beztalenciach. (...) Co za strata papieru!" ${ }^{45}$. Pojawiają się też zastrzeżenia dotyczące niepoprawnego politycznie ujęcia tematu. O tym, że sposób opisu innej kultury jest delikatną kwestią, świadczy przykład Marka Lawrence'a Schrada, autora książki Imperium wódki. Pijana polityka od Lenina do Putina. Świadomy niebezpieczeństwa, jakie stoi za przedstawianiem

43 J. Hammer, Cold Case Files, „New York Times”, 28.10.2010, https://www.nytimes. com/2010/10/31/books/review/Hammer-t.html, dostęp: 25.05.2021.

44 Zob. https://www.goodreads.com/book/show/13590706-white-fever?from _ search $=$ true\&from_srp=true\&qid $=$ W7cES23t5L\&rank=2, dostęp: 25.05.2021.

45 Tamże. 
„pijanej polityki” Rosji przez Amerykanina, naukową rozprawę badacz rozpoczyna od znanego w świecie akademickim chwytu odpierania potencjalnych zarzutów, pisząc:

korzyści płynące z racjonalnego i poważnego zwrócenia uwagi na problem alkoholu w Rosji znacznie przewyższają ryzyko trafienia w czyjś czuły punkt, konfrontacji z delikatnym, krępującym stereotypem czy kurtuazyjnego zignorowania tematu jako rzekomej kliszy ${ }^{46}$.

Niektóre recenzje brytyjskie robią wrażenie bardziej wnikliwych. Recenzent „Spectatora” nawiązuje do Thubrona ${ }^{47} \mathrm{i}$ podkreśla surwiwalowy charakter książki, a ekskursję Hugo-Badera nazywa „piekielną odyseją”. Hugh Thomsonowi z brytyjskiego „Independent” Biata goraczka kojarzy się natomiast z rodzimą twórczością Tima Butchera, autora między innymi Rzeki krwi, w której przedstawiona została jego wyprawa śladami Henry'ego Mortona Stanleya w Kongo ${ }^{48}$ (na marginesie książka nominowana była w Polsce do pierwszej Nagrody im. Ryszarda Kapuścińskiego). Carl Wilkinson z „Financial Timesa” nazywa Hugo-Badera reporterem „bystrym i ciekawskim”, podkreślając, że uogólnienie i komentarz ustępują w Biatej gorączce „błyskotliwym obrazkom ze spotkań z ludźmi”.

Koncentracja na human interest stories znalazła zrozumienie również u recenzentów Dzienników kotymskich. Komplementuje je Brytyjczyk Will Nicoll w „Wall Street Journal” ${ }^{49}$, natomiast Luke Harding w „The Guardian” pisze wręcz: „Siła tej książki polega na tym, że opiera się na ludzkich historiach, które wykraczają poza parametry konwencjonalnego reportażu prasowego" ${ }^{50}$.

W Wielkiej Brytanii książki Hugo-Badera były docenione przez krytyków. Biata goraczka została nominowana do brytyjskiej Dolman Best Travel Book Award (obecnie Edward Stanford Travel Writing Award). Nazwisko polskiego reportażysty znalazło się na krótkiej liście obok między innymi Colina Thubrona i Johna Gimlette’a (który wygrał). W kolejnych latach nominowanymi byli między innymi Kapka Kassabova, Paul Theroux, Sylvain Tesson i Robert Macfarlane, a w 2019 szansę miał Witold Szabłowski, doceniony za Tańczące niedźwiedzie ${ }^{51}$.

${ }^{46}$ M.L. Schrad, Imperium wódki. Pijana polityka od Lenina do Putina, tłum. A. Czwojdrak, Kraków 2015, s. 12-13.

47 L. Jones, The Last Place on Earth, „The Spectator”, 23.07.2011, https://www.spectator. co.uk/article/the-last-place-on-earth-, dostęp: 22.05.2021.

48 H. Thomson, “White Fever", By Jacek Hugo-Bader, „The Independent”, 22.10.2011, https://www.independent.co.uk/arts-entertainment/books/reviews/white-fever-jacek-hugo-bader-2372365.html, dostęp: 22.05.2021.

49 W. Nicoll, On the Road With the Ghosts of the Gulag, 15.07.2014, https://www.wsj.com/ articles/on-the-road-with-the-ghosts-of-the-gulag-1402860438, dostęp: 22.05.2021.

50 L. Harding, "White Fever" by Jacek Hugo-Bader - Review, 15.07.2011, https://www.theguardian.com/books/2011/jul/15/travel-writing-russia, dostęp: 22.05.2021.

51 W. Szabłowski, Dancing Bears: True Stories of People Nostalgic for Life Under Tyranny, tłum. A. Lloyd-Jones, New York 2018. 
Dzienniki kotymskie nagrodzono natomiast English Pen Award, co zostało podkreślone na okładce. Dostrzegli je także jurorzy Pushkin Prize, co poskutkowało między innymi wywiadem, w którym Hugo-Bader został zapytany, czy polska tolerancja na alkohol i zimno pomogła mu w procesie zbierania materiałów do Dzienników kotymskich (odpowiedział twierdząco) ${ }^{52}$.

Zaskakujące, że w amerykańskiej recepcji książek Jacka Hugo-Badera nie ma śladu powiązania sposobu pisania polskiego reportażysty z Nowym Nowym Dziennikarstwem, zdefiniowanym przez Roberta Boyntona ${ }^{53}$. Przypomnijmy, że zdaniem badacza New Journalism to zjawisko historyczne, natomiast w twórczości współczesnych autorów non-fiction (na liście Boyntona są między innymi Jon Krakauer i Ted Conover, którym bardzo blisko do poetyki Hugo-Badera) punkt ciężkości przesunięty został z literackiego opracowania faktów na sposób zbierania materiałów. Reportaże „nowych nowych dziennikarzy” są często, jeśli nie wcieleniowe, to przynajmniej uczestniczące, a praca nad tekstem przeciąga się w miesiące lub lata. Tę cechę pisarstwa Hugo-Badera wydobyto tylko w wywiadzie udzielonym izraelskiemu pismu „Haaretz” po tym, jak reporter odwiedził targi książki w Jerozolimie, promując przełożoną na hebrajski Biata gorączkę. Aviva Lori nazywa Polaka „dziennikarzem totalnym”, notując: „Jeśli nie je i nie pije tego, co jego bohaterowie, jeśli z nimi nie sypia i nie sika, jeśli nie wącha ich potu, wówczas historia nie jest idealna. A Hugo-Bader nigdy nie napisze historii, która nie jest perfekcyjna" ${ }^{4}$.

\section{Белая горячка. Obcy o nas}

Wprowadzając kontekst rosyjskiej i ukraińskiej recepcji książek Hugo-Badera, odniosę się do klasycznej już koncepcji Małgorzaty Czermińskiej dotyczącej kategorii punktu widzenia w tekstach niefikcjonalnych ${ }^{55}$. Przyglądając się trójkątowi komunikacyjnemu nadawca - przedmiot opisu - odbiorca w kontekście tożsamości kulturowej, badaczka wyróżniła trzy możliwe konfiguracje: „swój o swoim do innych”, „swój o tym, co inne do swoich” oraz „swój o tym, co inne do tych innych". Omawiane w tym szkicu książki lokowałabym w tej drugiej kategorii. Hugo-Bader zaznacza w wywiadach, że przyglądanie się rozpadowi ZSRR traktował jako kontynuację opisywania zmian zachodzących w transformującej się

52 A. Jack, Interview with Jacek Hugo-Bader, Author of Pushkin Prize 2015 Shortlisted Book "Kolyma Diaries", 31.10.2015, https://www.pushkinhouse.org/blog/interview-with-jacek-hugo-bader, dostęp: 22.05.2021.

53 R.S. Boynton, The New New Journalism: Conversations With America's Best Nonfiction Writers on Their Craft, New York 2005.

54 A. Lori, Road to Nowhere: The Polish Writer Who Exiled Himself to Siberia, 2.05.2013, https://www.haaretz.com/.premium-the-writer-who-exiled-himself-to-siberia-1.5240645, dostęp: 1.06.2021.

55 M. Czermińska, dz. cyt. 
Polsce. Punkt widzenia Polaka jest tu podkreślany, zarówno w rozmowach z bohaterami reportaży, jak i w autotematycznych wstawkach dotyczących reporterskiego modus operandi. Hugo-Bader dostrzega, że jest w Rosji zarówno „cudzesem” (bo przybyszem z zewnątrz), jak i „swojakiem” (bo przecież doświadczył na własnej skórze komunizmu). W rozmowie z Piotrem Brysaczem zauważył, że dystans sprzyja dziennikarzowi. Konsekwencją osiadłości i „zruszczenia” może być utrata „ostrości widzenia, a „dla reportera to śmierć”, bo przestaje się dziwić. Można przyjąć, że Hugo-Bader upozycjonował się jako korespondent z Polszy pomiędzy perspektywą Marsjanina i konwertyty, jak to ujął Fred Davis. Spojrzenie obcego, przyglądającego się zdarzeniom z dystansu i dziwującego się temu, co słyszy i dostrzega, nieustannie przechodzi w aktywność uczestnika, bawiącego się, zanurzającego w świat, podejmującego reguły gry autochtonów. Sytuacja zmienia się w momencie, gdy konfiguracja nadawczo-odbiorcza przechodzi w model „swój o tym, co inne dla innych", a właściwie - jeśli przyjąć perspektywę lekturową Rosjanina - „obcy o swoim dla swoich”.

Na Kołymskim Trakcie Jacek Hugo-Bader spotkał „doktora Włada”, głównego chirurga obwodowego szpitala w Magadanie. W restauracji spelunce o romantycznej nazwie Magnolia raczą się piwem z koniakiem, a w tym czasie pijany towarzysz reportera pomaga telefonicznie młodszym kolegom w przeprowadzaniu operacji złamania kości udowej. Z Magnolii, jak można się domyślać, wężykiem wyruszają na zwiedzanie miasta. Oprowadza chirurg. Idą główną ulicą, która wciąż jest prospektem Lenina, oglądają uliczne wizerunki Dmitrija Miedwiediewa i Władimira Putina. Hugo-Bader pyta, gdzie portrety Szałamowa, Kozina i innych artystów latami więzionych w łagrach.

Wład [syn oficera KGB - I.A.B.] opowiada mi z krzaków, w które runął, żeby się wysikać. Że patrzę na Rosję ze swojego małego, kulawego, europejskiego taborecika i że jak Rosjanie potępią swoją przeszłość, to nic im nie zostanie. Historia ich niełatwa. Łatwo obsikać sobie dwa palce - mówi filozoficznie Wład i znowu przewraca się w krzaki ${ }^{56}$.

Gdyby uogólnić zanotowaną przez reportera reakcję Rosjanina na polską perspektywę oglądu byłego ZSRR, być może zyskalibyśmy odpowiedź na pytanie, dlaczego w Rosji nie opublikowano ani Biatej goraczki, ani Dzienników kotymskich. W wywiadzie udzielonym ukraińskiemu pismu „Тиждень” Hugo-Bader mówił o Biatej goraczce:

Ta książka jest opisem postsowieckiego świata z perspektywy człowieka Zachodu, który potrafi jednak go zrozumieć, bo miał podobne doświadczenia, np. komunizm. To opowieść o Rosji, której Rosjanie nie chcą znać. Umówiłem się z dużą

56 J. Hugo-Bader, Dzienniki kotymskie, dz. cyt., s. 45. 
lokalną gazetą, że będą drukować moje reportaże, ale kiedy zobaczyli, jakie tabu łamię, nie chcieli czytać $^{57}$.

Kiedy w Wielkiej Brytanii Dzienniki kotymskie znalazły się na krótkiej liście nominowanych do Pushkin Prize, na pytanie, jak na jego reportaże reagują Rosjanie, Hugo-Bader odpowiedziat:

Moje książki o Rosji zostały przełożone na dziesięć języków i opublikowane we wszystkich najbardziej znaczących państwach europejskich, oprócz Rosji. Niektórzy liczący się wydawcy zgłaszali chęć wydania, zanim zostały ukończone, ale potem sugerowali, że nie są zainteresowani. Fragmenty zostały przełożone i opublikowane przez piratów na stronach rosyjskich internetowych. Strasznie mnie skrytykowano. Radzono mi, żebym skupił się na własnych sprawach, na nieszczęściach i bolączkach Polski, na polskich włóczęgach, złodziejach aut i alkoholikach. (...) mścili się na mnie, bo jestem Polakiem. Nie wolno mi pisać o Rosji w taki sposób ${ }^{58}$.

O tym, że perspektywa Jacka Hugo-Badera nie wpisuje się w oficjalną rosyjską narrację o byłym ZSRR, może świadczyć spostrzeżenie Aleksandra Silajewa na łamach krasnojarskiej gazety. Autor komplementuje Hugo-Badera między innymi za włóczęgostwo po Moskwie w towarzystwie bomżychy (bezdomnej), pisząc: „Oglądał nasze życie z takiej perspektywy, z jakiej my sami go nie widzimy" 59 . A także komentarze pod tekstem - ktoś cytuje amerykański dowcip o Polakach, ktoś zauważa, że „Polacy nigdy nie napiszą dobrze o Rosji”, ktoś inny nazywa Hugo-Badera „obłudną świnią?. W internetowym serwisie „Ukrajina Mołoda” napisano o wprost: „Nie trzeba dodawać, że książka [Biata goraczka - I.A.B.] nie została przetłumaczona na rosyjski”. Autor zauważa, że tytułowy reportaż przedrukowała „Zvezda”, ale - jak twierdzi - dlatego że jego bohaterami są Ewenkowie ${ }^{60}$.

Książki Hugo-Badera przełożył na język rosyjski Jurij Czajnikow ${ }^{61}$ (rocznik 1950), który ma na translatorskim koncie i nobliwych klasyków (Czesława Miłosza, Ryszarda Kapuścińskiego), i literacką młodzież (Michała Witkowskiego, Sylwię Chutnik). Czajnikow jest Don Kichotem literatury polskiej w Rosji - wprawdzie pracuje na zamówienie (tak trafił na Wojciecha

57 А. Бемей, Подорож глибинкою душ: автор „Білої гарячки” про спещибіку пострадянського npocmopy, https://tyzhden.ua/Culture/43125, dostęp: 22.05.2021.

58 A. Jack, dz. cyt.

59 А. Симаев, Яиек Хуго-Бадер: „Мьь перестали рассказыьвать анекдоты о русских”, „Вечерний Красноярск", 3.12.2010, nr 47 (288), https://newslab.ru/article/350311, dostęp: 22.05.2021.

60 В. Тихий, 12 тисяч км неофічійною Росією, „Україна Молода”, 19.11.2014, https:/ /www. umoloda.kiev.ua/number/2564/164/90499/, dostęp: 22.05.2021.

61 Fragment zob. https://umlautmestodeystviya.wordpress.com/2012/11/14/goraczkaexcerpt/, dostęp: 23.03.2021. 
Kuczoka i Gugarę Andrzeja Dybczaka), ale zdarza się, że tłumaczy książkę, która go zachwyci, a potem dopiero błąka się z nią po rosyjskich wydawnictwach. Tak było z Jackiem Hugo-Baderem. W 2009 roku Czajnikow przełożył Biata goraczkę, której fragment (tytułowy rozdział) wydrukowano mu w petersburskim miesięczniku „Zwiezda” (2009, nr 10), rok później - Dziennikikotymskie.

- To był obłęd, szaleństwo. Jakbym się zakochał. Zobaczyłem w tych reportażach kawał realnego życia, literackie mięso. Udało mi się podpisać umowę z dwoma wydawnictwami, Georgim Jeriominem i Letnij Sad, sam szukałem dofinansowania. Proponowałem nawet, żeby zgłosić się do producenta samochodów, który wypożyczył Jackowi auto na jedną z wypraw. Działałem jak wariat! Nic z tego, przepadło. Moje tłumaczenia trafiły do internetu, a książek jak nie było, tak nie ma. Teraz gotowe makiety leżą w petersburskim wydawnictwie Aleteja. Od znajomych dyplomatów i ludzi zajmujących się sztuką i literaturą zdarzyło mi się usłyszeć, że Jacek stereotypowo podchodzi do Rosji. Odpowiadam: „Napisz przedmowę, posłowie. Nawet gdyby ta książka miała przysporzyć kłopotów, korzyści i tak będzie znacznie więcej"

- opowiada tłumacz.

Trafnie w ujęciu historycznym i postzależnościowym polskie pisarstwo o Rosji zdiagnozował Przemysław Czapliński, dzieląc powtarzających „matryce narracyjne” podróżników na trzy kategorie: „wizytatorów” (charakteryzuje ich optyka dyscyplinująca; centralna postać korektora, tropiącego odstępstwa od „normy”; orientalizacja ${ }^{63}$ ), „zbieraczy” (to z kolei obserwacja uczestnicząca, koncentracja na praktykach życia codziennego) oraz „fingujących, tropicieli, tekstualistów” (kreują oni obrazu Rosji jako „niegotowej rzeczywistości”) ${ }^{64}$. W kategorii pierwszej autor Poruszonej mapy lokuje Ryszarda Kapuścińskiego, jako autora Imperium, oraz Krystynę Kurczab-Redlich, sugerując, że „zawozili [oni - I.A.B.] do Rosji zachodnie kryteria i skrzętnie odnotowywali rozmaite niezgodności" ${ }^{65}$. Inny sposób zbierania materiałów i pisania Czapliński dostrzega w tekstach Jacka $\mathrm{Hu}$ go-Badera, Jędrzeja Morawieckiego i Igora Miecika. Ich „zbieractwo uczestniczące" polega na cielesnym doświadczaniu prowincjonalnej codzienności Rosji. Trzecią praktykę pisarską, nazwaną „fingowaniem Rosji”, Czapliński odnajduje

${ }^{62}$ Korespondencja autorki artykułu z Jurijem Czajnikowem.

63 Pisząc o Kapuścińskim, Czapliński posługuje się pojęciem „tercjalizacji”, zarzuca autorowi Imperium przedstawianie Rosji jako Trzeciego Świata. Różnicę pomiędzy orientalizacją a tercjalizacją badacz dostrzega w przesunięciu akcentów - z kultury na gospodarkę i politykę.

${ }^{64}$ P. Czapliński, Poruszona mapa. Wyobraźnia geograficzno-kulturowa polskiej literatury przetomu XX i XXI wieku, Kraków 2016 [ebook], loc. 201-206.

65 M. Sutowski, P. Czapliński, Mamy mape, nie mamy narracji, https://krytykapolityczna. $\mathrm{pl} /$ kultura/czytaj-dalej/mamy-mape-nie-mamy-narracji-rozmowa-z-przemyslawem-czaplinskim/, dostęp: 2.05.2021. 
u Mariusza Wilka, twórcy „nowego języka, zakotwiczonego w doświadczeniu jednostkowym i poskładanego ze wspólnych, polsko-rosyjskich elementów" 66 . Uzupełniłabym tę listę o Michała Książka, który w publikacji Jakuck. Stownik miejsca łączy taktylność i kinetyczność Hugo-Badera z wyczuleniem na język, charakteryzującym pisarstwo Wilka. Typologia Czaplińskiego jest wartościująca „zbieractwo” badacz uważa otwarcie wprawdzie za praktykę uczciwszą niż „wizytowanie”, bo jego warunkiem jest skrócenie dystansu, zżyma się jednak na „poetyk[e] jawnego voyeuryzmu - ostentacyjnego podglądania cudzego rozkładu" ${ }^{67}$. Językowe eksperymenty Wilka - polsko-rosyjskie neologizmy odsłaniające wspólny rdzeń językowy, sięgające nie do angielskiego jako nowego lingua franca (makaronizmów i „dziwolągów z informatycznego slangu" ${ }^{68}$ ), lecz do słowiańszczyzny - interpretuje natomiast jako gotowość do budowania więzi, a więc motywację szlachetniejszą niż podglądactwo (między wierszami przewija się tu zarzut sensacyjności).

Można z tym ujęciem polemizować, ale jak wynika ze zgromadzonych powyżej przykładów, prowokacyjny „,oyeuryzm” Hugo-Badera irytuje rosyjskiego czytelnika. Pod opublikowanymi w internecie tekstami przełożonymi przez Czajnikowa (nazwisko tłumacza rzadko jest podawane) nie ma ożywionej dyskusji. Jeden z komentatorów napisał dosadnie: „Pojechał [Hugo-Bader - I.A.B.] do Papuasów i zauważył tylko tyle, że piją wódkę". Również w rosyjskich mediach niewiele jest informacji o polskim reporterze, który upodobał sobie na temat Rosję. Na zasadzie ciekawostki dziennik „Komsomolskaja Prawda” donosi, że „polski dziennikarz przyjechał do Władywostoku uazem", a za kierownicą pokonał samotnie 9 tys. km. Głównym celem tej publikacji jest pomoc w sprzedaży auta - redakcja publikuje ogłoszenie i podaje numer telefonu do reportera ${ }^{69}$.

Hugo-Bader jest natomiast obecny na Ukrainie, gdzie tak zwaną polską szkołę reportażu zaczęto promować w 2000 roku serią reporterską wydawnictwa Tempora. Jej redaktorzy inicjujący zaczęli od Mariusza Szczygła, Jacka Hugo-Badera i Witolda Szabłowskiego, klasyków - Kapuścińskiego i Krall - zostawiając na później ${ }^{70}$. W 2012 roku ukazała się ukraińska wersja Biatej gorączki, ze wstępem Szczygła (tym, w którym reporter kontrastuje optykę Hugo-Badera i Kapuścińskiego, posługując się metaforami szybującego ptaka i wałęsającego się psa). Reportaż przełożył Ostap Sluvynsky, poeta.

66 Tamże.

67 P. Czapliński, dz. cyt., loc. 501.

68 P. Brysacz, Patrząc na Wschód. Przestrzeń, cztowiek, mistycyzm, Kielce 2018 [e-book], loc. 546 .

69 Е. Астафурова, Польский журналист приехал во Владивосток на „УАЗе”, 26.02.2008, https://www.dv.kp.ru/daily/24055/300413/, dostęp: 22.05.2021.

70 Tempora opublikowała między innymi Bukareszt. Kurz i krew Małgorzaty Rejmer, Abchazję Wojciecha Góreckiego, Bieżeńców Anety Prymaki-Oniszk, Nasz maty PRL Izabeli Meyzy i Witolda Szabłowskiego, Tańczące niedźwiedzie i Zabójcę z miasta moreli Szabłowskiego. Zob. tempora.com.ua, dostęp: 22.05.2021. 
- Biata goraczka nie była dla mnie wyzwaniem w sensie profesjonalnym, ale emocjonalnym. Bo to bardzo trudna książka, a tłumacz bardzo głęboko przeżywa tekst. Na szczęście tłumaczyłem Biata gorączkę w Wiedniu, mogłem więc od czasu do czasu wyjść na spacer i ochłonąć w zupełnie innej rzeczywistości. Pewnie byłoby mi trudniej we Lwowie, gdzie, wyglądając przez okno, patrzę na bloki z wielkiej płyty - opowiada. - Ukraińcy zaczęli pisać reportaże właśnie pod wpływem polskiej szkoły reportażu, ale tematyka byłego ZSRR nie jest u nas popularna. Gdybym miał szukać odpowiednika Hugo-Badera na Ukrainie, byłby to Pavlo Stekh, który w Nad przepaściq $w r d z y$ dosadnie pokazuje ukraińską rzeczywistość, podróżując podmiejskimi pociągami ${ }^{71}$.

Z przeglądu ukraińskich recenzji ${ }^{72}$ można wywnioskować, że bardzo istotną płaszczyzną porozumienia jest kontekst postkolonialny. Skupia się na nim na przykład recenzentka pisma „Kritika”, podkreślając, że Hugo-Bader opisuje zombie, które pozostało po Imperium. „To dziennikarstwo, którego brak odczuwamy w krajowych mediach" - pisze $^{73}$. Z kolei recenzent kijowskiej gazety nazywa Biata goraczkę ,antykolonizacyjnym prysznicem”, konstatując:

Postsowiecka rzeczywistość ludów rosyjskiej północy wygląda jak apokalipsa denacjonalizacji, po której następuje śmierć zarówno poszczególnych osób, jak i całych grup etnicznych.

Opisując dno społeczne oraz historie i losy obywateli mieszkających w byłych republikach ZSRR, Jacek Hugo-Bader starał się osiągnąć jeden cel, a mianowicie uczciwie zaświadczać o wszystkich, z którymi dzielił chleb: na dworcach kolejowych w Moskwie wśród bezdomnych, z rodzinami górników z Doniecka lub na pastwiskach hodowców reniferów z rosyjskiej północy. Opisując to, o czym lokalna, a tym bardziej ogólnopolska prasa wstydliwie, „tolerancyjnie” milczy, stał się ich prawdziwym sojusznikiem i przyjacielem ${ }^{74}$.

Jedna z czytelniczek ukraińskiej Biatej goraczki zauważa: „Z perspektywy człowieka Zachodu mamy okazję spojrzeć świeżym okiem na problemy, których na

71 Prywatna korespondencja autorki artykułu z Ostapem Sluvynskym.

72 Zob. też: O. Nachlik, „Terytorium zaufania” - polski dyskurs wokót reportażu ukraińskiego oraz ukraińska recepcja reportażu polskiego jako wskaźnik zmian w polsko-ukraińskim dialogu kulturowym XXI wieku [w:] Literatura polska wświecie, t. 7: Reportaż wświecie, światowość reportażu, red. K. Frukacz, Katowice 2019, s. 39-56.

73 Ю. Ємець-Аоброносова, Яиек Гуго-Бадер, „Біла гарячка”, „Критика”, R. XIV, nr 5, https://krytyka.com/ua/reviews/bila-haryachka, dostęp: 22.05.2021.

74 С. Федорчук, „Біла гарячка” пострадянського світу. Книжку польського репортера Яцека Гуго-Бадера видано українською мовою, https://day.kyiv.ua/uk/article/kultura/bila-garyachka-postradyanskogo-svitu, dostęp: 2.06.2021. 
Ukrainie nie można nazwać wykorzenionymi. Picie prowadzi do zabójstw domowych, okaleczeń, niszczy losy i dobrobyt rodzin, rozbija małżeństwa"75.

O ukraińskiej recepcji Białej gorączki entuzjastycznie napisała Ołesia Nachlik, która zauważyła, że reportaż książkowy polskiego reportera świetnie funkcjonował poza specjalistycznym, hermetycznym środowiskiem badaczy literatury i mediów, co - jej zdaniem - sprawiło, że:

odbiór reportaży Hugo-Badera stał się jednym z impulsów do przeformatowania naszego postkolonialnego postrzegania siebie oraz Innego, do aktywnego zaangażowania w stopniowe oddalanie się od imperialnego rdzenia poprzez demontaż starego dziedzictwa kolonialnego, które wciąż definiuje naszą teraźniejszość i częściowo modeluje naszą przyszłość ${ }^{76}$.

Badaczka podkreśla, że dla ukraińskiego odbiorcy istotne było „odczytywanie tych tekstów przez pryzmat własnego doświadczenia egzystencji po upadku sowieckiego kolosa"77, a przekład Biatej goraczki stał się „mocnym bodźcem do przemyślenia przez Ukraińców fenomenu współczesnej Rosji i aktualizacji dyskusji o niezbędności przezwyciężenia tej zdeformowanej rzeczywistości delirium tremens" 78 .

Zebrany w tym szkicu materiał analityczny pokazuje, że „polska szkoła reportażu" nie jest globalnie nośną etykietą, choć nazwisko Kapuścińskiego może pomagać w promocji tekstów autorów nieznanych jeszcze za granicą. W znaczeniu wzorca uruchamiana jest przez ukraińskich badaczy, traktujących polskie non-fiction jako model uwspółcześnionego, zamerykanizowanego reportażu, którego niedobór obserwują na własnym lokalnym rynku wydawniczym (stąd omawiana w artykule inicjatywa oficyny Tempora). Prześledzenie zagranicznej recepcji książek Hugo-Badera - zarówno tej profesjonalnej, naukowej i krytycznoliterackiej, jak i „obywatelskiej” (komentarze czytelników zamieszczane w aplikacji Goodreads) - pozwoliło na pokazanie konsekwencji zmian warunków komunikacji literackiej, następujących w wyniku udostępnienia tekstu odbiorcom, dla których pierwotnie nie był on przeznaczony. Biata goraczka i Dzienniki kotymskie powstały z myślą o czytelniku polskim, z oczywistych względów zorientowanym w historii ZSRR, a zarazem nastawionym wobec niej jeśli nie demaskatorsko, to krytycznie (podobnie jak czytelnik ukraiński, co może wyjaśniać popularność Hugo-Badera na Ukrainie). Zmiana adresu skutkuje wytworzeniem napięcia pomiędzy czytelnikiem wewnątrztekstowym - tym, którego Michał Głowiński nazwał odbiorcą

75 Zob. https://www.livelib.ru/review/1094564-bila-garyachka-yatsek-gugobader, dostęp: 2.06.2021.

76 O. Nachlik, Пострадянські рещидиви і синдром постколоніальної пустки (на прикладі „Білої гарячки” Я. Гуго-Бадера), „Studia Ukrainika Posnaniensia” 2002, t. 8, nr 2, s. 172.

77 Tamże, s. 163 [streszczenie].

78 Tamże. 
wirtualnym ${ }^{79}$ - a zewnątrztekstowym, konkretnym, który może dysponować odmiennym horyzontem doświadczeń i którego czytelnicze przyzwyczajenia mogą być różne od projektowanych przez autora. Dla czytelnika amerykańskiego, przyzwyczajonego do sztywnych wzorców gatunkowych podyktowanych specyficzną globalną genologią rynkową, reportaże Hugo-Badera są zbyt nieoczywiste formalnie, a perspektywa Polaka wizytującego rozpadające się Imperium - niekiedy zanadto hermetyczna. To paradoks „polskiej szkoły reportażu”: żeby zyskać globalną popularność, teksty polskich reportażystów musiałyby wpasować się we wzorzec, do którego przyzwyczajono ponadlokalnego odbiorcę, stając się wówczas popularnym non-fiction. Próba wpisania książek Hugo-Badera przez amerykańskiego wydawcę w szereg przygodowych publikacji z nurtu survival non-fiction (Biata goraczka jako White Fever: A Journey to the Frozen Heart of Siberia, a Dzienniki kotymskie - A Journey into Russia's Haunted Hinterland) pokazuje, że nie jest to tylko kwestia etykietowania. Sięgając po anglojęzyczne wersje książek polskiego reportera, przyzwyczajeni do innych konwencji gatunkowych odbiorcy dali w recenzjach świadectwo czytelniczych konfuzji. Równie interesujące konsekwencje ma wprowadzenie w nowy kontekst odbiorczy tekstu, w którym antropologiczny punkt widzenia za Czermińską możemy określić jako „swój o innym dla swoich". Biata goraczka i Dzienniki kotymskie opowiadają o byłym ZSRR z perspektywy podmiotu kulturowo bliskiego, ale jednak zdystansowanego, „cudzesa-swojaka”, konwertyty i Marsjanina. Brak rosyjskich wydań może być konsekwencją przyjęcia przez reportera innej niż oficjalna w Rosji optyki. 12 tys. km nieoficjalna Rosja - tak zatytułowano recenzję Biatej goraczki, opublikowaną w piśmie „Ukrajina Mołoda”.

\section{Bibliografia}

Antonia Lloyd-Jones and Her Authors, http://authors-translators.blogspot.com/2016/01/ antonia-lloyd-jones-and-her-authors.html, dostęp: 27.05.2021.

Boynton R.S., The New New Journalism: Conversations With America's Best Nonfiction Writers on Their Craft, New York 2005.

Brysacz P., Patrzac na Wschód. Przestrzeń, cztowiek, mistycyzm, Kielce 2018 [e-book]. Czapliński P., Poruszona mapa. Wyobraźnia geograficzno-kulturowa polskiej literatury przetomu XX i XXI wieku, Kraków 2016 [ebook].

Czermińska M., „Punkt widzenia” jako kategoria antropologiczna i narracyjna w prozie niefikcjonalnej, „Teksty Drugie” 2003, nr 2-3.

Davis F., The Martian and the Convert, „Ontological Polarities in Social Research, Urban Life and Culture" 1973, vol. 2, iss. 3.

Frazier I., Podróże po Syberii, tłum. J. Korpanty, Warszawa 2013.

79 M. Głowiński, Wirtualny odbiorca w strukturze utworu poetyckiego [w:] tegoż, Prace wybrane, red. R. Nycz, t. 3: Dzieto wobec odbiorcy. Szkice z komunikacji literackiej, Kraków 1998. 
Gliński M., A Foreigner's Guide to Polish Reportage, https://culture.pl/en/article/a-foreigners-guide-to-polish-reportage, dostęp: 25.04.2021.

Głowiński M., Wirtualny odbiorca w strukturze utworu poetyckiego [w:] tegoż, Prace wybrane, red. R. Nycz, t. 3: Dzieto wobec odbiorcy. Szkice z komunikacji literackiej, Kraków 1998.

Golovko H.I., Польська школа літератури факту: герої репортажів як дзеркало

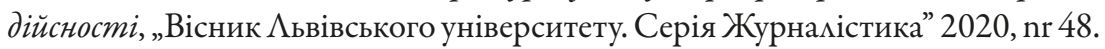

Golovko H.I., Польська школа художнього репортажу: історія та прочес розвиткух, „Соціальні комунікаціï”, http://pvs.uad.lviv.ua/static/media/1-77/12.pdf, dostęp: 28.05.2021.

Greenberg S., Kapuścinski and Beyond: The Polish School of Reportage [w:] Global Literary Journalism: Exploring the Journalistic Imagination, red. R.L. Keeble, J. Tulloch, New York 2012.

Hammer J., Cold Case Files, „New York Times”, 28.10.2010, https://www.nytimes. com/2010/10/31/books/review/Hammer-t.html, dostęp: 25.05.2021.

Harding L., "White Fever" by Jacek Hugo-Bader - Review, 15.07.2011, https://www. theguardian.com/books/2011/jul/15/travel-writing-russia, dostęp: 22.05.2021.

Hugo-Bader J., Biata goraczka, Wołowiec 2011.

Hugo-Bader J., Бiлa zapraчka, tłum. O. Sluvynsky, Kijów 2012.

Hugo-Bader J., Dzienniki kotymskie, Wołowiec 2011.

Hugo-Bader J., Kolyma Diaries: A Journey Into Russia's Haunted Hinterland, thum. A. Lloyd-Jones, London 2014.

Hugo-Bader J., White Fever: A Journey to the Frozen Siberia, thum. A. Lloyd-Jones, Berkley 2012; London 2012.

https://umlautmestodeystviya.wordpress.com/2012/11/14/goraczkaexcerpt/, dostęp: 23.03.2021.

Jack A., Interview with Jacek Hugo-Bader, Author of Pushkin Prize 2015 Shortlisted Book "Kolyma Diaries", 31.10.2015, https://www.pushkinhouse.org/blog/interview-with-jacek-hugo-bader, dostęp: 22.05.2021.

Jones L., The Last Place on Earth, „The Spectator”, 23.07.2011, https://www.spectator.co.uk/article/the-last-place-on-earth-, dostęp: 22.05.2021.

Lori A., Road to Nowhere: The Polish Writer Who Exiled Himself to Siberia, 2.05.2013, https://www.haaretz.com/.premium-the-writer-who-exiled-himself-to-siberia-1.5240645, dostęp: 1.06.2021.

Nachlik O., „Terytorium zaufania” - polski dyskurs wokót reportażu ukrainskiego oraz ukraińska recepcja reportażu polskiego jako wskaźnik zmian w polsko-ukraińskim dialogu kulturowym XXI wieku [w:] Literatura polskaw świecie, t. 7: Reportaż w'wiecie, światowość reportażu, red. K. Frukacz, Katowice 2019.

Nachlik O., Пострадянськірецидиви ісиндромпостколоніальної пустки (наприкладі „Білої арячки” Я. Гуго-Бадера), „Studia Ukrainika Posnaniensia” 2002, t. 8, nr 2.

Nicoll W., On the Road With the Ghosts of the Gulag, 15.07.2014, https://www.wsj. com/articles/on-the-road-with-the-ghosts-of-the-gulag-1402860438, dostęp: 22.05.2021. 
Roy V., The Constant Traveller, „The Hindu”, 4.01.2014, https://www.thehindu.com/ features/magazine/the-constant-traveller/article5538257.ece, dostęp: 2.05.2021.

Schrad M.L., Imperium wódki. Pijana polityka od Lenina do Putina, thum. A. Czwojdrak, Kraków 2015.

Shutiak L. [А.M. Шутяк], Польська школа художнього репортажк, „нформаційне суспімьство" 2016, nr 23.

Sutowski M., Czapliński P., Mamy mape, nie mamy narracji, https://krytykapolityczna.pl/kultura/czytaj-dalej/mamy-mape-nie-mamy-narracji-rozmowa-z-przemyslawem-czaplinskim/, dostęp: 2.05.2021.

Szabłowski W., Dancing Bears: True Stories of People Nostalgic for Life Under Tyranny, thum. A. Lloyd-Jones, New York 2018.

Thomson H., "White Fever", By Jacek Hugo-Bader, „The Independent”, 22.10.2011, https://www.independent.co.uk/arts-entertainment/books/reviews/white-fever-jacek-hugo-bader-2372365.html, dostęp: 22.05.2021.

Thubron C., Po Syberii, tłum. D. Kozińska, Wołowiec 2011.

Thubron C., Utracone serce Azji, tłum. D. Kozińska, Wołowiec 2012.

www.goodreads.com/book/show/13590706-white-fever?from_search=true\&from_ srp=true\&qid=W7cES23t5L\&rank=2, dostęp: 22.05.2021.

www.livelib.ru/review/1094564-bila-garyachka-yatsek-gugobader, dostęp: 2.06.2021.

Астафурова Е., Польскийжурналист приехал во Владивостокна „УАЗе”, 26.02.2008, https://www.dv.kp.ru/daily/24055/300413/ dostęp: 22.05.2021.

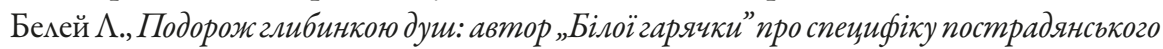
npocmopy, https://tyzhden.ua/Culture/43125, dostęp: 22.05.2021.

Симаев А., Яиек Хуго-Бадер: „Мьь перестали рассказывать анекдоты о русских”, „Вечерний Красноярск” 3.12.2010, nr 47 (288), https://newslab.ru/article/350311, dostęp: 22.05.2021.

Ємець-Аоброносова Ю., Ящек Гуго-Бадер, „Біла гарячка”, „Критика” R. XIV, nr 5 , https://krytyka.com/ua/reviews/bila-haryachka, dostęp: 22.05.2021.

Федорчук С., „Біла гарячка" пострадянського світу. Книжку польського репортера а Яиека Гуго-Бадера видано українською мовою, https://day.kyiv.ua/uk/article/kultura/bila-garyachka-postradyanskogo-svitu, dostęp: 2.06.2021.

Тихий В., 12 тисяч км неофічійною Росією, „Україна МолоАа”, 19.1 1.2014, https:// www.umoloda.kiev.ua/number/2564/164/90499/, dostęp: 22.05.2021. 